\title{
A randomized, double-blind, placebo-controlled, multiple-dose, parallel-group clinical trial to assess the effects of teduglutide on gastric emptying of liquids in healthy subjects
}

Jolene Kay Berg ${ }^{1 *}$, Eric H Kim², Benjamin $\mathrm{Li}^{2}$, Bo Joelsson² and Nader N Youssef ${ }^{2}$

\begin{abstract}
Background: Teduglutide, a recombinant analog of human glucagon-like peptide (GLP)-2, is a novel therapy recently approved for the treatment of adult patients with short bowel syndrome who are dependent on parenteral support. Previous studies assessing the effect of GLP-2 on gastric emptying in humans have yielded inconsistent results, with some studies showing no effect and others documenting a GLP-2-dependent delay in gastric emptying. The primary objective of this study was to assess the effect of teduglutide on gastric emptying of liquids in healthy subjects, as measured by the pharmacokinetics of acetaminophen.
\end{abstract}

Methods: This double-blind, parallel-group, single-center study enrolled and randomized 36 healthy subjects (22 men, 14 women) to receive subcutaneous doses of teduglutide $4 \mathrm{mg}$ or placebo (2:1 ratio; 23:13) once daily on Days 1 through 10 in the morning. Gastric emptying of a mixed nutrient liquid meal was assessed by measuring acetaminophen levels predose and at $0.25,0.5,0.75,1,1.25,1.5,2,3,3.5,4,5,6,8,10,12$, and 14 hours after administration of $1000 \mathrm{mg}$ acetaminophen on Days 0 and 10. The primary study endpoint was a pharmacokinetic analysis of acetaminophen absorption in subjects receiving teduglutide or placebo.

Results: No significant differences in gastric emptying of liquids (acetaminophen area under the concentration [AUC] vs time curve from time 0 to the last measurable concentration, AUC extrapolated to infinity, maximum concentration $\left[C_{\max }\right]$, and time to $\left.C_{\max }\right)$ were observed on Day 10 in subjects receiving teduglutide 4 mg versus subjects receiving placebo. There were no serious adverse events (AEs), deaths, or discontinuations due to an AE reported during the study.

Conclusions: Teduglutide $4 \mathrm{mg} /$ day for 10 days does not affect gastric emptying of liquids in healthy subjects as measured by acetaminophen pharmacokinetics. No unexpected safety signals were observed.

Trial registration: This study was registered at ClinicalTrials.gov, identifier NCT01209351.

Keywords: Teduglutide, Gastric emptying, Pharmacokinetics, Pharmacodynamics

\section{Background}

The proglucagon gene yields a single mRNA transcript expressed in the intestines, pancreas, and central nervous system (CNS) [1-3]. Tissue-specific cleavage of the resulting proglucagon precursor protein generates several peptides with distinct biological activity [3]. In the intestines, the proglucagon-derived proteins glucagon-

\footnotetext{
* Correspondence: jolene.berg@davita.com

'DaVita Clinical Research, 825 S. 8th Street, Suite 300, Minneapolis, MN 55404, USA

Full list of author information is available at the end of the article
}

like peptide (GLP)-1 and GLP-2 are expressed in the enteroendocrine $\mathrm{L}$ cells and are secreted in response to food intake [4-6]. The primary effects of GLP-1 are to increase postprandial insulin levels, inhibit glucagon secretion, and slow gastric emptying [7-15], whereas the primary effects of GLP-2 are to increase growth of intestinal epithelium, maintain intestinal mucosal morphology and function, and regulate energy intake [16-19]. Unlike GLP-1, GLP-2 has limited effect on insulin secretion or glucose homeostasis [20-22]. Furthermore, in

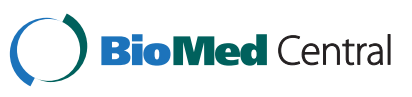


contrast to GLP-1, GLP-2 does not decrease pancreatic glucagon secretion [21,23].

Multiple animal and human studies have demonstrated a delay in gastric emptying with GLP-1 or glucagon, another protein encoded by the proglucagon gene [7-12,24,25]. Because GLP-1 and GLP-2 are both derived from proglucagon and secreted following nutrient stimulation, it has been hypothesized that they coregulate gastric motility [26]. Indeed, in preclinical studies, GLP-2 significantly decreased the amplitude and frequency of postprandial gastric contractions and promoted gastric muscle relaxation [26,27]. However, conflicting results have emerged from studies on human subjects, with some reporting no effect of GLP-2 and others demonstrating a GLP-2-dependent inhibition of gastric emptying [21,28-30]. The divergent outcomes may have been influenced by differences between the studies, including variations in the amounts of GLP-2 delivered, the methods used to evaluate gastric emptying, and the content of test meals administered [21,28-30].

Teduglutide, a recombinant GLP-2 analog, is a novel therapy recently approved for the treatment of adult patients with short bowel syndrome (SBS) who are dependent on parenteral support [31,32]. SBS is defined as a clinically significant reduction in intestinal absorptive capacity resulting from surgical resection of the intestine due to disease, trauma, congenital defects, or complications of surgery [33,34]. Teduglutide promotes expansion of the remaining normal intestinal epithelium by increasing villus height and crypt depth in the small bowel mucosa, leading to increased absorptive area [31,32,35]. In a phase III, placebo-controlled trial, teduglutide significantly reduced parenteral nutrition and/or intravenous fluid (PN/ IV) volume requirements and the number of infusion days required in patients with SBS [36].

Teduglutide is a synthetic protein that differs from native GLP-2 by the substitution of glycine for alanine at the second position from the N-terminus [37]. This single amino acid substitution renders it resistant to degradation by dipeptidyl peptidase-4 $[37,38]$. As a result, the half-life $\left(t_{1 / 2}\right)$ of teduglutide is increased compared with native GLP-2 following subcutaneous injection ( $t_{1 / 2}$ of $180-330$ minutes vs $60-90$ minutes, respectively) $[39,40]$. Because GLP-2 reduces gastric motility and delays gastric emptying, at least in animal and some human studies $[26,27,29,30]$, it is possible that teduglutide, a similar but distinct molecular entity, may also inhibit gastric emptying. Modification of gastric emptying rate may alter the bioavailability of concomitantly administered drugs and modulate drug-drug interactions [41]. Thus, given the recent approval of teduglutide, clarification of the physiological effects of this novel peptide would provide important information to the medical community.

The primary objective of this study was to assess the effect of teduglutide on gastric emptying of liquids in healthy subjects as gauged by acetaminophen pharmacokinetics (PK), an accepted measure of gastric emptying kinetics [42].

\section{Methods \\ Study design}

In this double-blind, single-center, US-based, parallelgroup study, 36 healthy domiciled subjects were randomized in a 2:1 ratio to receive subcutaneous teduglutide $4 \mathrm{mg}$ or placebo daily for 10 days (Figure 1).

Subjects were randomized according to a randomization scheme generated by the sponsor or their designee. All doses of study drug for each subject were taken from the kit designated for that subject. Both subjects and investigators were blinded to the identity of the study drug administered; vials containing teduglutide and placebo were identical in appearance.

The RCRC Independent Review Board, LLC, of Austin, TX approved the study protocol and informed consent procedure before study initiation. The study was conducted in accordance with the Declaration of Helsinki, applicable International Conference on Harmonisation

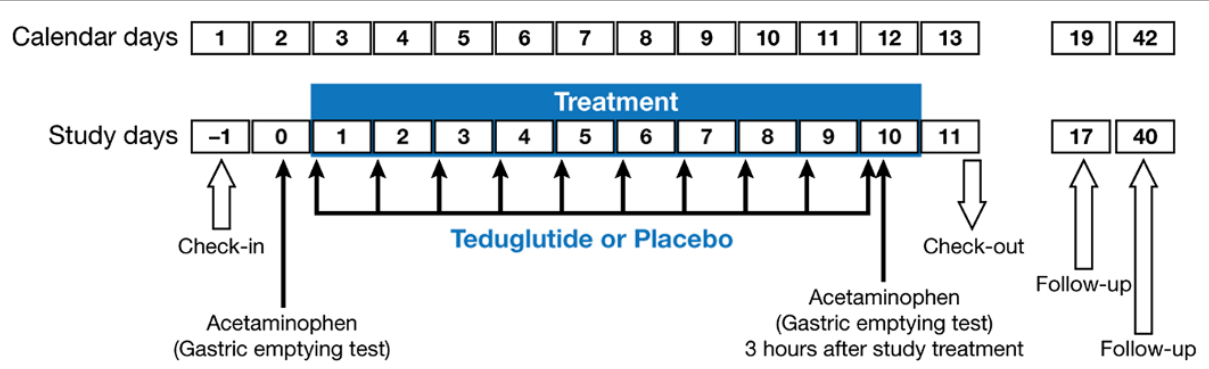

Teduglutide: $4 \mathrm{mg} \mathrm{SC}$ injections daily for 10 days

Placebo: SC injections daily for 10 days

Figure 1 Study design. SC = subcutaneous. 
Guidelines, and Good Clinical Practices. This study was registered at ClinicalTrials.gov, identifier NCT01209351.

\section{Subjects}

The study enrolled adults aged 18 to 45 years in good health who provided informed consent for participation. The study was conducted in healthy volunteers to eliminate the confounding effects of gastrointestinal (GI) disease. Key exclusion criteria included history of GI abnormality that could affect GI motility (including small bowel or colonic resection, inflammatory bowel disease, irritable bowel disease, and colon or GI tract cancer), allergy or sensitivity to acetaminophen, history of hepatitis or pancreatitis, evidence of liver inflammation, pregnancy or lactation, and body mass index $>30 \mathrm{~kg} / \mathrm{m}^{2}$. Prohibited prior and concomitant medications were generally those that may have affected gastric emptying, confounded efficacy or safety measurements, potentially posed a safety concern, or adversely potentiated or antagonized study drug treatment. Subjects were asked to abstain from alcoholic beverages and/or other alcoholcontaining products from 48 hours before check-in until the last scheduled evaluation and blood sample collection before discharge on Day 11. Caffeinated beverages were not allowed during the gastric emptying assessments on Days 0 and 10 because caffeine may affect gastric emptying [43]. Hormonal contraceptives were also prohibited based on the potential for interference with acetaminophen metabolism [44].

\section{Treatments}

Teduglutide $4 \mathrm{mg}$ or placebo was administered by daily subcutaneous abdominal injection in a volume of $0.4 \mathrm{~mL}$ in the morning on Days 1 through 10. On Day 10, study drug was administered following an overnight fast and 3 hours before administration of a commercially available liquid meal providing $240 \mathrm{kcal}$ and containing $10 \mathrm{~g}$ protein, $4 \mathrm{~g}$ fat, and $41 \mathrm{~g}$ carbohydrate (Boost ${ }^{\circ}$, Nestlé Healthcare Nutrition, Florham Park, NJ). To ensure treatment compliance, study medication was administered under the direct supervision of the site investigator.

Acetaminophen extra-strength liquid $1000 \mathrm{mg}(30 \mathrm{~mL})$ was administered on Days 0 and 10 immediately before a standard Boost meal and 3 hours after teduglutide or placebo on Day 10.

\section{Assessments}

\section{Pharmacodynamics of gastric emptying}

The primary study endpoint was a PK analysis of acetaminophen absorption in subjects receiving teduglutide or placebo. Blood levels of acetaminophen were measured at $0,0.25,0.5,0.75,1,1.25,1.5,2,3,3.5,4,5,6,8$, 10,12 , and 14 hours after acetaminophen administration on Days 0 and 10 (Table 1).

\section{Safety}

Safety assessments included monitoring of adverse events (AEs), clinical laboratory tests, electrocardiogram, physical examination, and vital signs. For each AE recorded, an intensity level (ie, mild, moderate, or severe) was assigned. Mild AEs generally did not interfere with daily activities, required no special treatment, and were usually transient. Moderate AEs impaired daily activities but were usually easily resolved. Severe AEs interrupted daily activities and required vigorous therapeutic intervention. Serious AEs and AEs considered related to study drug were recorded through 30 days after the last study drug dose.

\section{Statistical analysis}

The sample size of 36 was based on phase I considerations for hypothesis generation rather than power considerations. The intent-to-treat (ITT) population included all randomized subjects who received at least 1 dose of study medication and had at least $1 \mathrm{PK} /$ pharmacodynamic (PD) measurement. The PK/PD population included all subjects from the respective population who had at least 3 PK measurements. The safety population included all randomized subjects who received at least 1 dose of study drug and who had any follow-up information.

For acetaminophen absorption, PK parameters estimated from plasma concentration (Days 0 and 10) included area under the plasma concentration versus time curve (AUC) from time 0 to the last measurable concentration $\left(\mathrm{AUC}_{0-\text { last }}\right)$ and extrapolated to infinity $\left(\mathrm{AUC}_{0-\mathrm{inf}}\right)$, maximum plasma concentration $\left(C_{\max }\right)$, and time to $C_{\max }$ $\left(t_{\text {max }}\right)$. PK parameters were estimated from the actual time of sampling and were calculated using noncompartmental analysis. Analysis of covariance (ANCOVA) using baseline (Day 0) values and sex as covariates was used to analyze the acetaminophen PK data and calculate differences in gastric emptying of liquids between teduglutide and placebo for AUC and $\mathrm{C}_{\max }$ parameters. A rank-adjusted nonparametric ANCOVA was used for $t_{\max }$.

Safety data were summarized using descriptive statistics for quantitative data and frequency counts for qualitative data. AEs were coded using Medical Dictionary for Regulatory Activities terminology.

SAS/STAT ${ }^{\circ}$ version 9.1 (SAS Institute, Cary, NC) was used to analyze the data.

\section{Results}

\section{Subject disposition}

Between September and November 2010, 36 subjects were randomized to receive teduglutide $(n=23)$ or placebo $(n=13)$. All subjects received at least 1 dose of study medication and had at least 1 PK measurement (ITT population). In the placebo group, 1 subject withdrew consent for personal reasons and discontinued 
Table 1 Day 10 gastric emptying and pharmacokinetic schedule

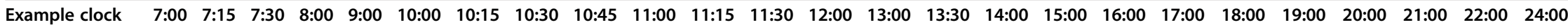
time

Gastric emptying

0

0.25

$0.50 \quad 0.75$

$1.25 \quad 1.5$

2

3.5

4

6

8

10

Teduglutide $\quad X$

administration

Acetaminophen

administration

$x$

Standard meal*

"Standard solid meal; dinner could have been given at any time following the last biomarker draw. 
Table 2 Subject demographics

\begin{tabular}{|c|c|c|}
\hline Demographic variable & Placebo $(n=13)$ & Teduglutide $4 \mathrm{mg}(\mathrm{n}=23)$ \\
\hline Mean (SD) age, y & $32.5(7.0)$ & $31.4(7.4)$ \\
\hline Mean (SD) weight, kg & $80.9(12.4)$ & $70.3(12.0)$ \\
\hline Mean (SD) height, $\mathrm{cm}$ & $173.6(10.7)$ & $169.0(8.7)$ \\
\hline $\begin{array}{l}\text { Mean (SD) body } \\
\text { mass index, } \mathrm{kg} / \mathrm{m}^{2}\end{array}$ & $26.7(2.2)$ & $24.5(3.1)$ \\
\hline \multicolumn{3}{|l|}{ Sex, n (\%) } \\
\hline Male & $8(62)$ & $14(61)$ \\
\hline Female & $5(38)$ & $9(39)$ \\
\hline \multicolumn{3}{|l|}{ Race, n (\%) } \\
\hline Black & $4(31)$ & $5(22)$ \\
\hline White & $9(69)$ & $18(78)$ \\
\hline \multicolumn{3}{|l|}{ Ethnicity, n (\%) } \\
\hline Hispanic or Latino & $8(62)$ & $17(74)$ \\
\hline $\begin{array}{l}\text { Not Hispanic } \\
\text { or Latino }\end{array}$ & $5(38)$ & $6(26)$ \\
\hline
\end{tabular}

from the study after 7 days of treatment. This subject was not included in the PK/PD population. Subjects were well matched for demographics and baseline characteristics between the 2 groups (Table 2).

\section{Gastric emptying}

Compared with placebo, teduglutide treatment for 10 days had no appreciable effect on gastric emptying of liquids as determined by acetaminophen PK parameters. Although acetaminophen absorption appears to be somewhat higher in the teduglutide group compared with the placebo group on both Day 0 and Day 10, the absorption curves for the teduglutide group and the placebo group on Day 10 were not significantly different from the corresponding curves on Day 0 (Figure 2A and B). The Day 10 absorption curves also did not differ significantly between the treatment groups. At Day 10, no significant differences were observed between the 2 groups in $\mathrm{AUC}_{0-\text { last }}, \mathrm{AUC}_{0-\text { inf }}, \mathrm{C}_{\max }$, or $\mathrm{t}_{\max }$ (Table 3). Within the teduglutide group, acetaminophen PK parameters were similar at Day 0 and Day $10\left(\mathrm{AUC}_{0-\text { last }}\right.$, $60,105 \pm 13,028$ vs $60,984 \pm 15,710 \mathrm{ng} \cdot \mathrm{hour} / \mathrm{mL}$, respectively;

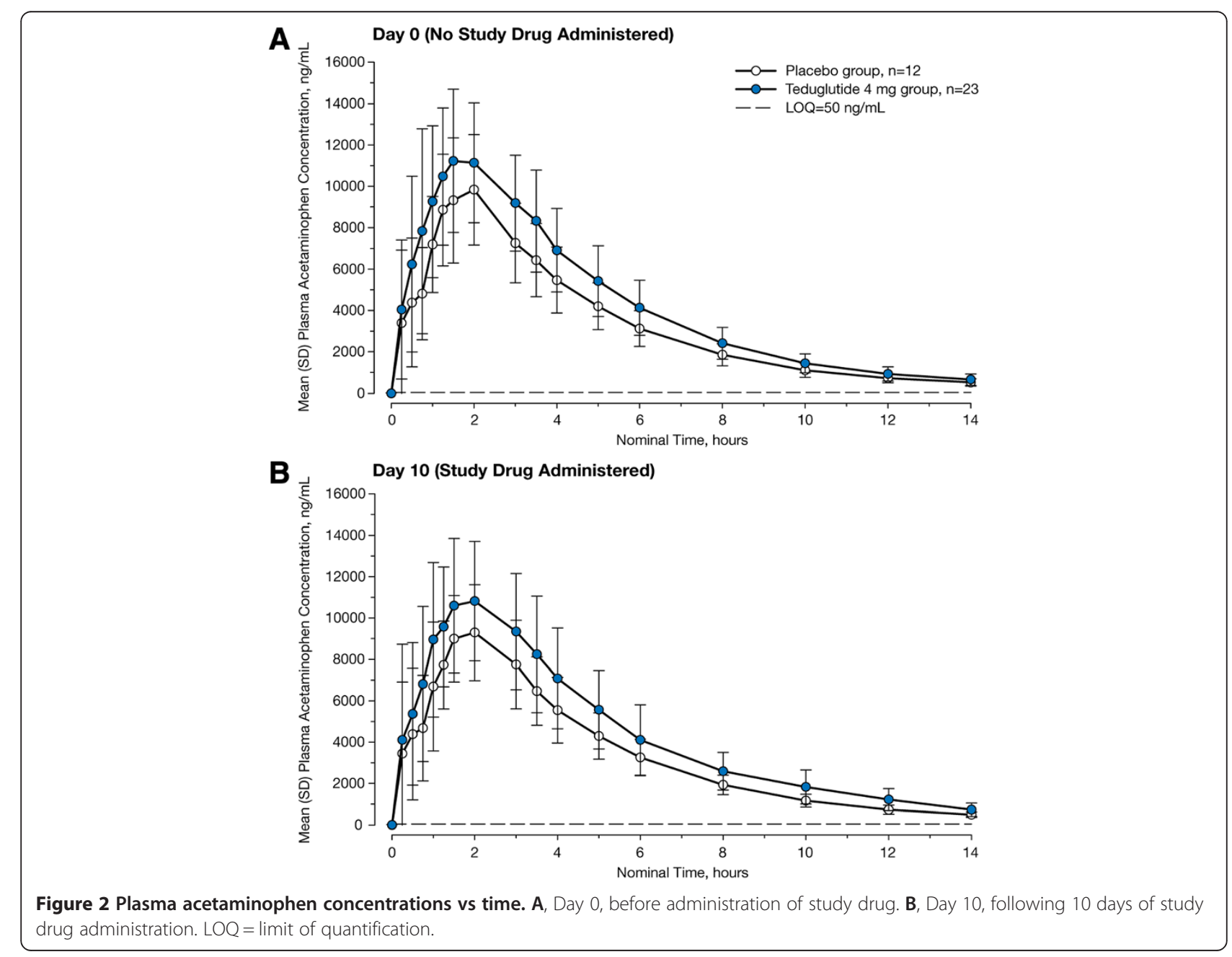


Table 3 Acetaminophen pharmacokinetic parameters on day 10 (PK/PD population*)

\begin{tabular}{|c|c|c|c|}
\hline Pharmacokinetic parameter, mean \pm SD & Placebo $(n=12)$ & Teduglutide $4 \mathrm{mg}(\mathrm{n}=23)$ & $P$ value \\
\hline $\mathrm{AUC}_{\text {O-last, }}$ ng.hour $/ \mathrm{mL}$ & $47,652 \pm 9377$ & $60,984 \pm 15,710$ & 0.32 \\
\hline $\mathrm{AUC}_{0-\text { inf, }} \mathrm{ng} \cdot \mathrm{hour} / \mathrm{mL}$ & $50,036 \pm 9706$ & $65,279 \pm 17,039$ & 0.26 \\
\hline$C_{\max }, \mathrm{ng} / \mathrm{mL}$ & $10,679 \pm 2246$ & $12,677 \pm 3821$ & 0.28 \\
\hline$t_{\max }$, hour & 1.5 & 1.7 & 0.65 \\
\hline
\end{tabular}

$A U C=$ area under the curve; $A U C_{0-\text { last }}=A U C$ from time 0 to the last measurable concentration; $A U C_{0 \text {-inf }}=A U C$ from time 0 extrapolated to infinity; $C_{\max }=$ maximum plasma concentration; $P D=$ pharmacodynamic; $P K=$ pharmacokinetic; $t_{\max }=$ time to $C_{\max }$.

*1 patient in the placebo group withdrew consent on Day 7 and therefore did not have PK/PD data for Day 10.

$\mathrm{AUC}_{0-\text { inf }}, 63,693 \pm 14,187$ vs $65,279 \pm 17,039$ ng.hour $/ \mathrm{mL}$; $\mathrm{C}_{\max }, 13,319 \pm 3155$ vs $12,677 \pm 3821 \mathrm{ng} / \mathrm{mL} ; \mathrm{t}_{\max }, 1.6$ vs 1.7 hour). Similarly, the placebo group showed no apparent differences in PK parameters at Day 0 versus Day 10 (AUC $_{0-\text { last, }}, 47,551 \pm 9483$ vs 47,652 \pm 9377 ng.hour $/ \mathrm{mL}$, respectively; $\quad \mathrm{AUC}_{0-\text { inf, }} \quad 50,360 \pm 10,001$ vs 50,036 \pm 9706 ng.hour/mL; $C_{\max }, 11,124 \pm 2939$ vs $10,679 \pm 2246$ ng/ $\mathrm{mL} ; \mathrm{t}_{\max }, 1.5$ vs 1.5 hour).

\section{Safety}

Treatment-emergent AEs for subjects who received at least 1 dose of study drug with any follow-up information are shown in Table 4. Overall, 23 (64\%) subjects experienced a treatment-emergent $\mathrm{AE}$. There were no serious AEs, deaths, or discontinuations due to an AE during the study. Mild and moderate AEs were reported in 20 subjects (56\%) and 3 subjects (8\%), respectively; no severe AEs were reported. Changes from baseline in clinical laboratory parameters, electrocardiogram, physical examination, and vital signs were not clinically significant.

\section{Discussion}

In this study, teduglutide administered at $4 \mathrm{mg} /$ day for 10 days did not affect gastric emptying of liquids in healthy subjects as measured by acetaminophen PK. Previous studies evaluating gastric emptying following administration of GLP-2, a similar but distinct molecular entity, have yielded conflicting results [21,28-30]. Comparisons with and among these studies are hampered by heterogeneities in trial design, study populations, GLP-2 dosages, routes of GLP-2 administration, and timing of treatments. Nonetheless, results with teduglutide presented here are in agreement with 2 prior studies demonstrating no effect of infused native GLP-2 (0.75-2.25 $\mathrm{pmol} \cdot \mathrm{kg}^{-1} \cdot \mathrm{min}^{-1}$ for $180-390$ minutes) on gastric emptying rate following a 250-to 310-kcal solid meal, as determined by either scintigraphic measurement or ${ }^{13} \mathrm{C}$-sodium octanoate breath test $[21,28]$. In contrast, 2 other studies have reported delayed gastric emptying with GLP-2 $[29,30]$. In one of these studies, conducted in healthy adults following a $7.5-\mathrm{kcal}$ liquid meal, antral emptying time was increased by 9.5 minutes following GLP-2 (initial bolus of $4.5 \mathrm{pmol} / \mathrm{kg}$ followed by infusion at
$1.0 \mathrm{pmol} \cdot \mathrm{kg}^{-1} \cdot \mathrm{min}^{-1}$ for 60 minutes) compared with placebo $(P=0.049)$, as determined by ultrasound scanning. GLP-2 infused at a lower rate $\left(0.5 \mathrm{pmol} \cdot \mathrm{kg}^{-1} \cdot \mathrm{min}^{-1}\right)$ after the initial bolus did not significantly affect antral emptying time [29]. Contrary to the modest results reported by Nagell et al., Jeppesen et al. described a 30 -minute increase in time to $50 \%$ gastric emptying of solids following 35 days of treatment with subcutaneous GLP-2 (400 $\mu$ g twice daily; $P=0.002)$ using a scintigraphic technique [30]. In this case, however, the study enrolled patients with SBS who may have had baseline disturbances in gastric emptying. For example, half of the patients in the Jeppesen study had an end-jejunostomy, which in a previous study was correlated with accelerated emptying of gastric liquids for patients with SBS [45]. Furthermore, end-jejunostomy patients have diminished intestinal secretion of GLP-2 [30,46]. For these reasons, GLP-2 may have a greater effect on gastric emptying in the endjejunostomy population.

The liquid meal provided to study subjects contained fats in addition to carbohydrates and proteins. Previous studies suggest that the lipid phase empties more slowly than the aqueous phase in the context of a mixed solidliquid meal $[47,48]$. However, when fats are homogenized with liquids before ingestion, as is the case with a liquid-only meal, both fats and the aqueous phase empty at the same rate [49]. Therefore, it is likely that the data

Table 4 Treatment-emergent adverse events reported in $\geq 5 \%$ of subjects in the teduglutide group

\begin{tabular}{lcc}
\hline Variable, $\mathbf{n}(\mathbf{\%})$ & Placebo $(\mathbf{n}=\mathbf{1 3})$ & Teduglutide $\mathbf{4} \mathbf{~ m g}(\mathbf{n}=\mathbf{2 3})$ \\
\hline Treatment-emergent AEs & $9(69)$ & $14(61)$ \\
Abdominal distention & $2(15)$ & $8(35)$ \\
Constipation & $2(15)$ & $5(22)$ \\
Headache & $2(15)$ & $5(22)$ \\
Abdominal pain & $1(8)$ & $5(22)$ \\
Nausea & 0 & $5(22)$ \\
Dyspepsia & 0 & $2(9)$ \\
Eructation & 0 & $2(9)$ \\
Extremity pain & 0 & $2(9)$ \\
\hline
\end{tabular}

$\mathrm{AE}=$ adverse event. 
from this study reflect simultaneous gastric emptying of both fats and the aqueous phase of the liquid meal.

Recently, rapid tachyphylaxis has been documented for GLP-1-dependent inhibition of gastric emptying in humans following prolonged infusion [50], prompting the question of whether the physiological effects of GLP-2 or teduglutide could also be affected by tachyphylaxis. Presently, however, no data are available concerning the potential for tachyphylaxis with GLP-2 or teduglutide with regard to gastric emptying. Of the 4 published studies evaluating the effects of GLP-2 on gastric emptying in humans, none provided multiple measurements of gastric emptying following GLP-2 administration $[21,28-30]$. The results presented in this study show no effect of teduglutide on gastric emptying following 10 days of subcutaneous administration; however, the study was not designed to evaluate gastric emptying rates earlier in the treatment period, or following multiple meals consumed within a period of less than 24 hours. However, several studies have demonstrated sustained biological activity of GLP-2 or teduglutide over extended treatment periods. For example, mice who received subcutaneous GLP-2 for 12 weeks showed a progressive increase in small bowel weight over the course of the study [17]. Patients with SBS treated with subcutaneous teduglutide $(0.05 \mathrm{mg} / \mathrm{kg} /$ day $)$ experienced continued reductions in PN/IV volume requirements throughout a 52-week study. Furthermore, 11 of 19 patients in the same study who were nonresponders following 24 weeks of teduglutide achieved a clinically significant response, defined as a $\geq 20 \%$ reduction in PN/IV volume from baseline, by Week 52 [51]. These data indirectly suggest continued improvement with long-term teduglutide treatment, with no dampening of response.

Teduglutide was well tolerated in this study. No unexpected safety signals were observed. AEs were generally mild, with no severe AEs reported. The most common AEs observed in this study were gastrointestinal related, which is consistent with the known mechanism of action of teduglutide. These results are also in agreement with clinical trials for teduglutide conducted in patients with SBS dependent on parenteral support. In two 6-month, placebo-controlled, phase III studies, gastrointestinal-related AEs were the most frequently reported class of AEs among patients receiving $0.05 \mathrm{mg} / \mathrm{kg} /$ day teduglutide $[31,36]$.

This study was limited by the small sample size and use of healthy volunteers. Furthermore, the methods applied in this study assess gastric emptying of liquids only. However, the appearance of ingested acetaminophen in the plasma is an established and validated measure of gastric emptying kinetics [42] and has been used extensively in the analysis of GLP-1 receptor agonists [52-57].

\section{Conclusions}

The results presented here suggest that teduglutide does not act to delay liquid-phase gastric emptying in healthy subjects. Therefore, teduglutide is unlikely to modulate the bioavailability of orally administered concomitant medications through inhibition of gastric motility in this population. However, the effects of teduglutide on gastric emptying in patients with SBS remain to be investigated.

\begin{abstract}
Abbreviations
AEs: Adverse events; ANCOVA: Analysis of covariance; AUC: Area under the plasma concentration versus time curve; $A_{U} C_{0-i n f}$. Area under the plasma concentration versus time curve from time 0 extrapolated to infinity; $\mathrm{AUC}_{0 \text {-last: }}$ : Area under the plasma concentration versus time curve from time 0 to the last measurable concentration; $C_{\text {max }}$ : Maximum concentration; CNS: Central nervous system; Gl: Gastrointestinal; GLP: Glucagon-like peptide; ITT: Intent to treat; LOQ: Limit of quantification; PD: Pharmacodynamic; PK: Pharmacokinetics; PN/IV: Parenteral nutrition and/or intravenous fluid; SBS: Short bowel syndrome; SC: Subcutaneous; $t_{\text {max }}$ : Time to maximum concentration.
\end{abstract}

\section{Competing interests}

$J$ K Berg was an employee of the PRACS Institute, which contracted with NPS to perform the study. E H Kim, B Li, B Joelsson, and N N Youssef are employees of NPS Pharmaceuticals, Inc. This study was funded in full by NPS Pharmaceuticals, Inc. Initial data analyses were undertaken by the PRACS Institute and supported by NPS Pharmaceuticals, Inc.

\section{Authors' contributions}

JB carried out the study. BL performed the statistical analyses. EK, BJ, and NY analyzed the data. All authors assisted in drafting and/or revising the manuscript and approved the final version of the manuscript.

\section{Acknowledgements}

Writing support was provided by Heather Heerssen, PhD, of Complete Healthcare Communications, Inc. (Chadds Ford, PA, USA) and was funded by NPS Pharmaceuticals, Inc.

\section{Funding}

This study was funded by NPS Pharmaceuticals, Inc.

\section{Author details}

${ }^{1}$ DaVita Clinical Research, 825 S. 8th Street, Suite 300, Minneapolis, MN 55404, USA. ${ }^{2}$ NPS Pharmaceuticals, Inc, 550 Hills Drive, Bedminster, NJ 07921, USA.

Received: 4 April 2013 Accepted: 24 January 2014

Published: 12 February 2014

\section{References}

1. Drucker DJ, Asa S: Glucagon gene expression in vertebrate brain. J Biol Chem 1988, 263(27):13475-13478.

2. Drucker DJ, Brubaker PL: Proglucagon gene expression is regulated by a cyclic AMP-dependent pathway in rat intestine. Proc Natl Acad Sci USA 1989, 86(11):3953-3957.

3. Baggio LL, Drucker DJ: Clinical endocrinology and metabolism. Glucagon-like peptide-1 and glucagon-like peptide-2. Best Pract Res Clin Endocrinol Metab 2004, 18(4):531-554.

4. Orskov C, Holst JJ, Knuhtsen S, Baldissera FG, Poulsen SS, Nielsen OV: Glucagon-like peptides GLP-1 and GLP-2, predicted products of the glucagon gene, are secreted separately from pig small intestine but not pancreas. Endocrinology 1986, 119(4):1467-1475.

5. Elliott RM, Morgan LM, Tredger JA, Deacon S, Wright J, Marks V: Glucagon-like peptide-1 (7-36)amide and glucose-dependent insulinotropic polypeptide secretion in response to nutrient ingestion in man: acute post-prandial and 24-h secretion patterns. J Endocrinol 1993, 138(1):159-166.

6. Xiao Q, Boushey RP, Drucker DJ, Brubaker PL: Secretion of the intestinotropic hormone glucagon-like peptide 2 is differentially regulated by nutrients in humans. Gastroenterology 1999, 117(1):99-105.

7. Anvari M, Paterson CA, Daniel EE, McDonald TJ: Effects of GLP-1 on gastric emptying, antropyloric motility, and transpyloric flow in response to a nonnutrient liquid. Dig Dis Sci 1998, 43(6):1133-1140.

8. Imeryuz N, Yegen BC, Bozkurt A, Coskun T, Villanueva-Penacarrillo ML, Ulusoy NB: Glucagon-like peptide-1 inhibits gastric emptying via vagal 
afferent-mediated central mechanisms. Am J Physiol 1997 273(4 Pt 1):G920-927.

9. Naslund E, Gutniak M, Skogar S, Rossner S, Hellstrom PM: Glucagon-like peptide 1 increases the period of postprandial satiety and slows gastric emptying in obese men. Am J Clin Nutr 1998, 68(3):525-530.

10. Rotondo A, Amato A, Lentini L, Baldassano S, Mule F: Glucagon-like peptide-1 relaxes gastric antrum through nitric oxide in mice. Peptides 2011, 32(1):60-64.

11. Tolessa T, Gutniak M, Holst JJ, Efendic S, Hellstrom PM: Glucagon-like peptide- 1 retards gastric emptying and small bowel transit in the rat: effect mediated through central or enteric nervous mechanisms. Dig Dis Sci 1998, 43(10):2284-2290.

12. Wettergren $A$, Wojdemann $M$, Holst JJ: The inhibitory effect of glucagon-like peptide-1 (7-36)amide on antral motility is antagonized by its N-terminally truncated primary metabolite GLP-1 (9-36)amide. Peptides 1998, 19(5):877-882.

13. Fehmann HC, Habener JF: Insulinotropic hormone glucagon-like peptide-I (7-37) stimulation of proinsulin gene expression and proinsulin biosynthesis in insulinoma beta TC-1 cells. Endocrinology 1992, 130(1):159-166.

14. Orskov C, Holst JJ, Nielsen OV: Effect of truncated glucagon-like peptide-1 [proglucagon-(78-107) amide] on endocrine secretion from pig pancreas, antrum, and nonantral stomach. Endocrinology 1988, 123(4):2009-2013.

15. Kreymann B, Williams G, Ghatei MA, Bloom SR: Glucagon-like peptide-1 7-36: a physiological incretin in man. Lancet 1987, 2(8571):1300-1304.

16. Drucker DJ, Erlich P, Asa SL, Brubaker PL: Induction of intestinal epithelial proliferation by glucagon-like peptide 2. Proc Natl Acad Sci USA 1996, 93(15):7911-7916.

17. Tsai CH, Hill M, Asa SL, Brubaker PL, Drucker DJ: Intestinal growth-promoting properties of glucagon-like peptide-2 in mice. Am J Physiol Endocrinol Metab 1997, 273:E77-84.

18. Benjamin MA, McKay DM, Yang PC, Cameron H, Perdue MH: Glucagon-like peptide-2 enhances intestinal epithelial barrier function of both transcellular and paracellular pathways in the mouse. Gut 2000, 47(1):112-119.

19. Kato Y, Yu D, Schwartz MZ: Glucagonlike peptide-2 enhances small intestinal absorptive function and mucosal mass in vivo. J Pediatr Surg 1999, 34(1):18-20. discussion 20-11.

20. Sorensen LB, Flint A, Raben A, Hartmann B, Holst JJ, Astrup A: No effect of physiological concentrations of glucagon-like peptide-2 on appetite and energy intake in normal weight subjects. Int J Obes Relat Metab Disord 2003, 27(4):450-456.

21. Meier JJ, Nauck MA, Pott A, Heinze K, Goetze O, Bulut K, Schmidt WE, Gallwitz B, Holst JJ: Glucagon-like peptide 2 stimulates glucagon secretion, enhances lipid absorption, and inhibits gastric acid secretion in humans. Gastroenterology 2006, 130(1):44-54.

22. Schmidt WE, Siegel EG, Creutzfeldt W: Glucagon-like peptide-1 but not glucagon-like peptide- 2 stimulates insulin release from isolated rat pancreatic islets. Diabetologia 1985, 28(9):704-707.

23. Hvidberg A, Nielsen MT, Hilsted J, Orskov C, Holst JJ: Effect of glucagon-like peptide-1 (proglucagon 78-107amide) on hepatic glucose production in healthy man. Metabolism 1994, 43(1):104-108.

24. Jonderko G, Jonderko K, Golab T: Effect of glucagon on gastric emptying and on postprandial gastrin and insulin release in man. Mater Med Pol 1989, 21(2):92-96.

25. Mochiki E, Suzuki H, Takenoshita S, Nagamachi Y, Kuwano H, Mizumoto A, Itoh $Z$ : Mechanism of inhibitory effect of glucagon on gastrointestinal motility and cause of side effects of glucagon. J Gastroenterol 1998, 33(6):835-841.

26. Wojdemann M, Wettergren A, Hartmann B, Holst JJ: Glucagon-like peptide-2 inhibits centrally induced antral motility in pigs. Scand J Gastroentero/ 1998, 33(8):828-832.

27. Amato A, Baldassano S, Serio R, Mule F: Glucagon-like peptide-2 relaxes mouse stomach through vasoactive intestinal peptide release. Am J Physiol Gastrointest Liver Physiol 2009, 296(3):G678-684

28. Schmidt PT, Naslund E, Gryback P, Jacobsson H, Hartmann B, Holst JJ, Hellstrom PM: Peripheral administration of GLP-2 to humans has no effect on gastric emptying or satiety. Regul Pept 2003, 116(1-3):21-25.

29. Nagell CF, Wettergren A, Pedersen JF, Mortensen D, Holst JJ: Glucagon-like peptide- 2 inhibits antral emptying in man, but is not as potent as glucagon-like peptide-1. Scand J Gastroenterol 2004, 39(4):353-358.

30. Jeppesen PB, Hartmann B, Thulesen J, Graff J, Lohmann J, Hansen BS, Tofteng F, Poulsen SS, Madsen JL, Holst JJ, et al: Glucagon-like peptide 2 improves nutrient absorption and nutritional status in short-bowel patients with no colon. Gastroenterology 2001, 120(4):806-815.
31. Jeppesen PB, Gilroy R, Pertkiewicz M, Allard JP, Messing B, O'Keefe SJ: Randomised placebo-controlled trial of teduglutide in reducing parenteral nutrition and/or intravenous fluid requirements in patients with short bowel syndrome. Gut 2011, 60(7):902-914.

32. Jeppesen PB, Sanguinetti EL, Buchman A, Howard L, Scolapio JS, Ziegler TR, Gregory J, Tappenden KA, Holst J, Mortensen PB: Teduglutide (ALX-0600), a dipeptidyl peptidase IV resistant glucagon-like peptide 2 analogue, improves intestinal function in short bowel syndrome patients. Gut 2005, 54(9):1224-1231.

33. Hollwarth ME: Short bowel syndrome: pathophysiological and clinical aspects. Pathophysiology 1999, 6:1-19.

34. O'Keefe SJ, Buchman AL, Fishbein TM, Jeejeebhoy KN, Jeppesen PB, Shaffer $\mathrm{J}$ : Short bowel syndrome and intestinal failure: consensus definitions and overview. Clin Gastroenterol Hepatol 2006, 4(1):6-10.

35. Tappenden K, Edelman J: Teduglutide, a glucagon-like peptide-2 (GLP-2) analog, enhances the structure of the small intestinal mucosa in parenteral support-dependent short bowel syndrome-intestinal failure (SBS-IF) subjects without inducing dysplasia. Am J Gastroenterol 2011, 106:S98.

36. Jeppesen PB, Pertkiewicz M, Seidner DL, O'Keefe S, Heinze H, Joelsson B: Teduglutide, a novel analogue of glucagon-like peptide 2 (GLP-2), is effective and safe in reducing parenteral support volume in short bowel syndromeintestinal failure subjects: results from a 24-week, placebo-controlled phase 3 trial (STEPS). Gastroenterology 2011, 140(5 Suppl 1):S146.

37. Drucker DJ, Shi Q, Crivici A, Sumner-Smith M, Tavares W, Hill M, DeForest L, Cooper S, Brubaker PL: Regulation of the biological activity of glucagonlike peptide 2 in vivo by dipeptidyl peptidase IV. Nat Biotechnol 1997, 15(7):673-677.

38. Tavares W, Drucker DJ, Brubaker PL: Enzymatic- and renal-dependent catabolism of the intestinotropic hormone glucagon-like peptide-2 in rats. Am J Physiol Endocrinol Metab 2000, 278(1):E134-139.

39. Marier JF, Beliveau M, Mouksassi MS, Shaw P, Cyran J, Kesavan J, Wallens J, Zahir H, Wells D, Caminis J: Pharmacokinetics, safety, and tolerability of teduglutide, a glucagon-like peptide-2 (GLP-2) analog, following multiple ascending subcutaneous administrations in healthy subjects. J Clin Pharmacol 2008, 48(11):1289-1299.

40. Henriksen DB, Alexandersen P, Hartmann B, Adrian CL, Byrjalsen I, Bone HG, Holst JJ, Christiansen C: Four-month treatment with GLP-2 significantly increases hip BMD: a randomized, placebo-controlled, dose-ranging study in postmenopausal women with low BMD. Bone 2009, 45(5):833-842.

41. Kimura T, Higaki K: Gastrointestinal transit and drug absorption. Biol Pharm Bull 2002, 25(2):149-164.

42. Clements JA, Heading RC, Nimmo WS, Prescott LF: Kinetics of acetaminophen absorption and gastric emptying in man. Clin Pharmacol Ther 1978, 24(4):420-431

43. Lien HC, Chen GH, Chang CS, Kao CH, Wang SJ: The effect of coffee on gastric emptying. Nucl Med Commun 1995, 16(11):923-926.

44. Miners JO, Attwood J, Birkett DJ: Influence of sex and oral contraceptive steroids on paracetamol metabolism. Br J Clin Pharmacol 1983, 16(5):503-509.

45. Nightingale JM, Kamm MA, van der Sijp JR, Morris GP, Walker ER, Mather SJ, Britton KE, Lennard-Jones JE: Disturbed gastric emptying in the short bowel syndrome. Evidence for a 'colonic brake'. Gut 1993, 34(9):1171-1176.

46. Jeppesen PB, Hartmann B, Hansen BS, Thulesen J, Holst JJ, Mortensen PB: Impaired meal stimulated glucagon-like peptide 2 response in ileal resected short bowel patients with intestinal failure. Gut 1999, 45(4):559-563.

47. Jian R, Vigneron N, Najean Y, Bernier JJ: Gastric emptying and intragastric distribution of lipids in man. A new scintigraphic method of study. Dig Dis Sci 1982, 27(8):705-711.

48. Cortot A, Phillips SF, Malagelada JR: Gastric emptying of lipids after ingestion of a solid-liquid meal in humans. Gastroenterology 1981, 80(5 pt 1):922-927.

49. Cortot A, Phillips SF, Malagelada JR: Gastric emptying of lipids after ingestion of an homogenized meal. Gastroenterology 1979, 76(5 Pt 1):939-944.

50. Nauck MA, Kemmeries G, Holst JJ, Meier JJ: Rapid tachyphylaxis of the glucagon-like peptide 1-induced deceleration of gastric emptying in humans. Diabetes 2011, 60(5):1561-1565.

51. O'Keefe SJ, Jeppesen PB, Gilroy R, Pertkiewicz M, Allard JP, Messing B: Safety and efficacy of teduglutide after 52 weeks of treatment in patients with short bowel syndrome-intestinal failure. Clin Gastroenterol Hepatol 2013, 11(7):815-823

52. Kolterman OG, Buse JB, Fineman MS, Gaines E, Heintz S, Bicsak TA, Taylor K, Kim D, Aisporna M, Wang Y, et al: Synthetic exendin-4 (exenatide) 
significantly reduces postprandial and fasting plasma glucose in subjects with type 2 diabetes. J Clin Endocrinol Metab 2003, 88(7):3082-3089.

53. Cervera A, Wajcberg E, Sriwijitkamol A, Fernandez M, Zuo P, Triplitt C,

Musi N, DeFronzo RA, Cersosimo E: Mechanism of action of exenatide to reduce postprandial hyperglycemia in type 2 diabetes. Am J Physiol Endocrinol Metab 2008, 294(5):E846-852

54. Dupre J, Behme MT, McDonald TJ: Exendin-4 normalized postcibal glycemic excursions in type 1 diabetes. $J$ Clin Endocrinol Metab 2004, 89(7):3469-3473.

55. Edwards CM, Stanley SA, Davis R, Brynes AE, Frost GS, Seal $\amalg$, Ghatei MA, Bloom SR: Exendin-4 reduces fasting and postprandial glucose and decreases energy intake in healthy volunteers. Am J Physiol Endocrinol Metab 2001, 281(1):E155-161.

56. Kolterman OG, Kim DD, Shen L, Ruggles JA, Nielsen LL, Fineman MS, Baron AD: Pharmacokinetics, pharmacodynamics, and safety of exenatide in patients with type 2 diabetes mellitus. Am J Health Syst Pharm 2005, 62(2):173-181

57. DeFronzo RA, Okerson T, Viswanathan P, Guan X, Holcombe JH, MacConell $L$ : Effects of exenatide versus sitagliptin on postprandial glucose, insulin and glucagon secretion, gastric emptying, and caloric intake: a randomized, cross-over study. Curr Med Res Opin 2008, 24(10):2943-2952.

doi:10.1186/1471-230X-14-25

Cite this article as: Berg et al:: A randomized, double-blind, placebocontrolled, multiple-dose, parallel-group clinical trial to assess the effects of teduglutide on gastric emptying of liquids in healthy subjects. BMC Gastroenterology 2014 14:25.

\section{Submit your next manuscript to BioMed Central and take full advantage of:}

- Convenient online submission

- Thorough peer review

- No space constraints or color figure charges

- Immediate publication on acceptance

- Inclusion in PubMed, CAS, Scopus and Google Scholar

- Research which is freely available for redistribution 